\title{
Cable TV, Public Education, AZT, And A Shared Pond: Three Case Incidents In Government, Business And Ethics
}

Roy B. Johnson, Southern Utah University, USA

\begin{abstract}
This submission consists of three case incidents or vignettes with a focus on decisions rather than details. The paper includes original cases, case questions and reviews of those questions for the instructor. The common perspective of government, business and social responsibility unites these cases.

The first case begins with the cable TV industry and ends with public education. It examines the relationship between government and business in these two distinct environments.

The second case concerns Burroughs-Wellcome and its pricing of the anti-aids drug AZT. Protesters complained that the price of the drug was too high for many people to afford and picketed the company, which insisted that it was only doing its job and making a profit.
\end{abstract}

The third case is an environmental case which serves as a platform to investigate the relation between government and business in a commons situation.

Keywords: Case Incidents; Government; Business; Ethics

\section{INTRODUCTION}

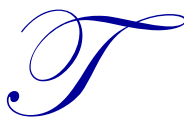

his submission includes three short cases of the type that the Society for Case Research calls "Case Incidents". "Unlike a long case, the incident does not provide historical detail or how the situation developed. Rather, it provides a snapshot that stimulates student use of their knowledge to arrive at a course of action or analysis." (www.sfcr.org). These shorter cases do not require that level of time and effort from the students in mastering factual situations that longer cases might, yet they still raise multiple theoretical and practical issues and present a valuable forum for student analysis. This form is well-respected in the business ethics literature. Because case incidents are shorter than full-length cases, three of them have been included in this submission. While detailed cases have their uses, short, clean vignettes allow multiple issues to be discussed and time to be focused on application rather than unnecessary detail. Both have value in appropriate circumstances.

These cases are intended for a Business, Government and Society or Business Ethics course and concern the relationships among business, government, and ethics. The first case consists primarily of investigating the respective roles of government and business in Capitalist societies. The second primarily deals with business and social responsibility and, secondarily, of government regulation, ethics and stakeholder analysis. The third case covers similar issues, but in an environmental setting.

As is typical of critical incidents, the cases themselves are simple, but their analyses can range from the simple introduction of issues to questions on final exams. They are most useful in class discussion and facilitate the complicated analysis and application of the concepts found in these courses. As such, the time taken on the cases may vary from ten to fifteen minutes each to a full class period. In general, the cases are intended for students at the undergraduate level; however, the potential difficulty level lies in the analysis rather than the cases themselves. 


\section{CASE ONE: CABLE TV AND PUBLIC EDUCATION - GOVERNMENT REGULATION AND SUPPORT}

Cable TV is a big part of many people's lives. For that reason, some people think that the government ought to be the cable service provider for its citizens and provide cable access to all. Others think that the free market would do a better job of providing cable services and government ought to stay out of it altogether. Still others think that private companies should provide cable, but that the government should regulate these companies to ensure competition. Finally, some think that there should be regulation, but it should be limited to content rather than delivery.

Public education is an even more important part of our society. Elementary and secondary schools have been organized, funded, and run by government agencies from early in the history of the United States. Currently, some people are arguing that, like cable T.V., education could be privately funded, organized and/or run. Others contend that education is a unique social good that ought to be available to everyone and not be left to private enterprise, but must be controlled by government.

What Should Government's Role Be In The Cable T.V. Industry? Should The Government Regulate The Cable TV Industry? How And Why?

Many students will argue that in Capitalism most goods and services should be produced and distributed by private business without the involvement of government. This is the basic assumption of laissez faire government in Capitalism. This theoretical foundation and its exceptions should be covered in this case.

Students will have been taught the reasons for regulation in Capitalist systems, which include failure of the assumptions of Capitalism - rational consumers, full and accurate information, costs/benefits contained in transactions (no externalities), functioning institutions of Capitalism (including private property, free enterprise, free markets, competition), natural monopolies, and non-economic values in the public interest.

The interesting thing about cable TV in the United States is that the industry is currently wholly regulated as a natural monopoly. There is no competition in the industry and prices and service are controlled by government commissions. The case can be well-used to review natural monopolies and discuss whether such regulation is still valid for this industry. Natural monopolies are defined as exceptions to normal competitive industries where, because of natural conditions, a single firm can supply the entire market more efficiently than several competing firms. This originally applied to cable TV because the natural conditions of laying cable to each household made it cheaper to have a monopoly lay the lines than several competing firms. While firms were thus given monopoly power, that power also had to be regulated so as not to be abused.

It can also be shown how modern technology can change the natural conditions to a point where competition becomes viable. In the cable TV industry, competition may be found, not in cable per se, but in satellite $\mathrm{TV}$, internet broadcasting, and telephone video service providers.

The other reasons for government involvement should be discussed, but none seems to be a strong reason for regulation of delivery in this case. Students can make the case for regulation of content (sex, violence, and language restrictions) on the basis of negative externalities, irrational consumption, and values in the public interest. The issue of free speech will be raised but should not distract from the focus on business and government.

When You Are Done Answering These Questions For Cable TV, Answer The Same Questions For Public Education; I.E., Should Schools Be Run, Funded, And/Or Regulated By The Government?

The purpose of this addition to the cable TV question is for students to examine whether the fact that 'the good an industry produces is a public good' makes a difference as to government involvement. By starting with cable TV, the foundations of government in the Capitalist system can be established for a more common type of service. These foundations can then be applied to the less common good of education. This can lead to a discussion of the specific functions of government that should be reserved to that institution and not given to private business. 
A key distinction between business and government lies in the alternative goals of equity and efficiency. Unconstrained business activity maximizes economic efficiency. What is desired from an economy, however, is not only efficiency in production, but equity in distribution. The focus of the social involvement of government in the economy is based on the notion of equity. This contrast forms a foundation for the discussion of public versus private control of education. The argument for private control of education lies in the power of efficiency, a better product at a lower cost. The argument for government control of education lies in the need to provide education for all - that the rich not receive a better education than the poor.

While it is important to recognize and analyze these arguments, grounds for compromise may also be found which use the best of efficiency and equity. This might be achieved through charter schools, school choice, government funding and regulation with business control, etc. Students can then see the value of win-win rather than either/or solutions.

Do Your Answers Differ, Why Or Why Not? Make Sure That You Support Your Answers, Noting The Respective Roles Of Government And Business In Our Society And The Reasons For Regulation.

The big difference between cable TV and public education is its broad impact on the general public. A democracy is dependent on an educated electorate and a Capitalist economy is dependent on an educated workforce. In economic terms, this is considered a positive externality and externalities - positive and negative - are not fully accounted for in unregulated Capitalist markets.

It is important that students not base government involvement on incorrect distinctions, like the importance of education. This leads to the false conclusion that important economic concerns need to be handled by government, while trivial concerns are what business should control. The analysis of the differences needs to be rooted in the framework and assumptions of Capitalism.

In each of these questions, the important thing is that students understand the framework for analysis and are able to apply it, not necessarily that they have the right outcome of that argument per se.

\section{CASE TWO: AZT AND PHARMACEUTICAL PRICING}

A while ago, four AIDS activists came to Research Triangle Park, North Carolina, and barricaded themselves inside the headquarters of Burroughs-Wellcome, the manufacturer of what, at the time, was the only effective FDA-approved anti-AIDS drug, AZT. Burroughs-Wellcome held the patent on this drug, giving it exclusive rights to the manufacture and sale of AZT for several years. The activists were protesting the high price of the drug (ca. \$10,000 for one year's requirements), which was too expensive for many people who are dying of the disease. The activists claimed that Burroughs-Wellcome was making an excessive profit at a cost of thousands of lives. Burroughs-Wellcome claimed the price was the lowest possible at which it could gain a reasonable return for its shareholders and recoup the research and development costs it incurred in developing the drug. Today, as the United States reconsiders the issue of health care and the roles of government and business in health care, the case of Burroughs-Wellcome and its responsibilities has a renewed importance.

Should Burroughs Wellcome Do Anything Differently, Why Or Why Not? Should The Government Get Involved? If You Were The CEO Of Burroughs Wellcome (BW), How Would You Resolve This Conflict?

This case should be analyzed in terms of Capitalist economic analysis, stakeholder analysis, ethical analysis and that of social responsibility. Each of these will have been covered earlier in the course or can be raised at the beginning to illustrate the structure of issues to come. These questions are open-ended enough to require the students to remember and apply the framework of business and society analysis. Alternatively, the instructor could ask specifically for analysis of what BW should do relative to each of these categories of analysis.

\section{Capitalism}

The Capitalist system and its assumptions should be the foundation of the analysis of this question. It should start with the initial assumption of a limited role of government in business affairs. The reasons for 
regulation (noted above) should also be examined. A major issue here is that the patent on AZT gives BW monopoly power. Since there is no competition, BW can set its prices without recourse to market value. This power also eliminates BW's incentive to improve the product or lower costs - the major economic value of the Capitalist system. The incentive value of patents can be discussed, but the fact that there is no competition for this drug should be addressed.

On the other hand, lowering the price for this drug decreases the retained earnings available to BW to invest in research and development and new products, which may actually help more people than lowering the price would.

Social Responsibility

Social responsibility may be argued for based on moral grounds (covered below) and by arguments for long-term self-interest. By lowering its price, BW stands to gain in better public relations and in avoidance of government regulation. It also ensures the security of the patent system. In South Africa, for example, the government, believing the price of AZT to be too high, chose to ignore BW's patent and manufacture generic AZT to serve its people. There was little BW could do about this. If providing drugs at a reasonable price is seen as part of the legitimacy of pharmaceutical companies, BW's perceived lack of legitimacy could lead to boycotts of its other products (a danger shown by the pickets in this case) and government regulation. BW can avoid this essentially by regulating itself.

\section{Ethics}

The issue of what is legally, morally, and ethically required in this situation should be addressed. BW has the power to save the lives of people who are dying and is pricing them out of the market. Legally there is nothing wrong with what BW is doing. Some will use this as a guide to the rightness of BW's behavior, but it should be emphasized that legal is not the same as moral or ethical. Moral behavior should be analyzed by moral systems and analysis. Ethics consists of the community consensus of what is right or wrong. Both of these need to be looked at and give a solid reason for social responsibility on BW's behalf.

It is important that this analysis be carefully carried out and that a knee-jerk reaction of sympathy to those suffering is avoided. It may be in BW's power to help, but is still not their responsibility.

\section{Stakeholders}

In a practical sense in their own self-interest, BW needs to manage its stakeholders. There are picketers at its headquarters, thus the media will be involved. BW needs to consider both its owners and its customers. Students should apply basic stakeholder analysis to this case.

\section{CASE THREE: A SHARED POND - UNDERSTANDING ENVIRONMENTAL POLICY}

You work for a textile firm that has been in the same location for decades. The firm has always dumped certain non-toxic waste into a nearby pond. To your knowledge, the firm has always been in compliance with government standards. Over the past five years, a small housing development has been started around the pond. You have received more and more complaints about your dumping. You now understand that the town is thinking about prohibiting all dumping into the pond. Your boss, the president of the company, is furious. He cannot understand why the government is changing the rules in the middle of the game. He cannot understand why townspeople are not sensitive to the current crisis in the industry when they contemplate actions that would raise his costs significantly. Finally, he believes that he was there first.

\section{What Advice Could You Give Your Boss That Would Help Him Understand The Situation?}

This case adds a wrinkle to the standard structure of analysis illustrated above, though the same type of analysis is also relevant here. The difference is that this is an environmental situation and, as an open public good, it raises the problem called "the tragedy of the commons." 
A commons situation exists whenever three characteristics hold: it is free to the user and available to all, it is finite, and finally, costs of use go to the community and benefits of use go to the individual. These characteristics are typical of most environmental situations, including the pond in the case above.

In a commons situation, the interest of the individual diverges from the interest of the group. Because there was no cost for the company's dumping, it was in its interest to do so. This posed no problem as long as the carrying capacity of the pond (the ability of a system to sustain a certain usage without degradation to the system) was not exceeded; but as others moved in and began using the pond as well, a threshold was crossed and the capacity of the pond was exceeded. Even though the firm was there first, it has no property rights to the shared commons; so its use is not privileged. The people are insensitive to the firm's situation because they are looking out for their own self-interest.

The government has changed the rules because the situation has changed. The capacity of the pond has been exceeded, and continued use at this level will destroy its value for all who want to use it. Since the free market does not produce the greatest public good in a commons situation (due to the characteristics of the commons and due to the negative externalities of the dumping), there is market failure and the government must step in to regulate the usage of the pond. Regulations to solve a commons problem should address the characteristics of the commons that cause the individual and public interests to diverge. These can include harmonizing the costs and the benefits so that both go to the community (Socialist solution) or both go to the individual (Capitalist solution). In other words, either limit the use while sharing the benefits among all of the people or limit the use by making those who gain the benefit of the resource pay for it. If it is possible, the finite nature of the resource can be addressed by finding new sources of the resource or increasing the amount of resource available (e.g., through technology, as in the green revolution). This solution is difficult for most environmental situations.

The analogy developed in the case can be applied to many other situations, helping students understand the unique nature of commons and its impact on economic assumptions. People naturally have incentives to overuse natural resources, to over fish, over hunt, and overuse land, oceans, water and air.

\section{RECOMMENDATIONS FOR TEACHING APPROACHES}

These cases are designed for a Business and Society course and can be used to introduce the issues to be covered in the course or to apply the concepts that have been learned. It can be a valuable exercise to use these cases at both the beginning and the end of a course. The students will see the improvements in analysis that brought about by the framework covered in the course. The instructor can make assignments on a team or individual basis. Students should be required to develop responses to the assignment questions, the detail of which should be relative to whether the cases are being used to introduce or examine the concepts from the course.

These cases are supplemental to texts in these courses which will outline the generally standardized content of the analysis to be used. The cases are to be used to examine the practical implications of, or to introduce, the content that is to be learned.

\section{AUTHOR INFORMATION}

Roy Johnson, JD, $\mathrm{PhD}$ is a professor of business management at Southern Utah University, Department of Management, Marketing and Hospitality, 351 West Center, Cedar City, Utah, 84720. His interests include the relationships between government, business, and society; and ethics. E-mail: johnsonr@suu.edu 


\section{NOTES}

